\title{
Safe School to Deal with Bullying at School in Industrial Revolution 4,0 Era: A Study Review
}

\author{
Akbar $\mathrm{Z}^{1}$, Wirasti $\mathrm{M}^{2}$, Putri $\mathrm{T}^{3}$, Aisyawati $\mathrm{M}^{4}$, \& Kusuma $\mathrm{M}^{5}$ \\ \{zarina_akbar@unj.ac.id ${ }^{1}$, murti@unj.ac.id ${ }^{2}$, tiaratrisna@gmail.com ${ }^{3}$, aisyamaratini@gmail.com ${ }^{4}$, \\ megaadinda21@gmail.com $\left.{ }^{5}\right\}$ \\ 1,2,3,4,5 Universitas Negeri Jakarta, Indonesia
}

\begin{abstract}
Children spend more time in school in their daily lives. Therefore, the school is the closest environment to children besides the family environment. This certainly does not rule out the possibility that children can experience abuse or violence in school or commonly referred to as bullying. Bullying in schools is rampant in Indonesia and is one of the main reasons children commit suicide. Therefore, it is necessary to create a school environment that can ensure the safety of children both physically and non-physically so that the learning process and development of children in schools can run optimally. The school environment is better known as Safe School is very important nowadays especially in industrial revolution 4,0 era.
\end{abstract}

\section{Keywords: Safe School, Bullying, Students}

\section{Introduction}

Schools and teachers are two things that greatly affect children's lives and have a longterm impact on children's attitudes and behavior. At school, children learn to shape their relationships with others, self-image, and independence. They try to foster interpersonal abilities, find and improve the strengths they have, and fight against vulnerabilities. Thus schools must provide a safe environment for children to develop academically, relationally, emotionally, and behaviorally (Dorian, 2004). Various studies have examined how education and the social climate of a school can increase or decrease student development and achievement. Researchers have found common characteristics in schools that are positive. These general characteristics include an emphasis on academic achievement, a positive relationship between students and teachers, respect for all members of the school, policies of fair and consistent discipline, attention to security issues, and the involvement of families and communities (Dorian, 2004).

Most educators agree that creating a safe school is more than removing knives, fights and shootings. Violence can also be in the form of simple things such as calling someone's name with an inappropriate name (name calling), fear of being teased, teasing, offensive touch, racial, ethnic, cultural, or sexual humiliation, and intimidation (Hernandez \& Steem, 2004). Without adequate monitoring, reporting and referral mechanisms, children in schools often face severe physical punishment, violence from friends to friends and sexual abuse or exploitation. Actors can include teachers, other authority figures and staff of international organizations and non-governmental organizations. The risk of exploitation and abuse is higher at the upper and basic levels, when children reach adolescence. The nature of the violence inflicted on children in the learning environment can be emotional, physical and 
psychological, and ranges from the subtle to the very explicit (UNHCR).

The United Nation has stated that $40 \%$ of children in Indonesia are victims of oppression in Indonesia (Herlinda, 2015). Previous research on violence against Indonesian children conducted by the Global School-based Student Health Survey (GSHS) (in Hadiyono \& Saraswati, 2015) identified that $40 \%$ of 80 million Indonesian children aged between 13 and 15 years had intimidated experiences physically at school (Saraswati \& Hadiyono, 2015). Many cases of violence against children occur in schools, whether it is done by students to students, or from teachers to students so that not a few causes trauma to injury to students (Viva news, 2018). The Indonesian Child Protection Commission/Komisi Perlindungan Anak Indonesia (KPAI) noted that in 2012 there was an increase in school cases of violence against children to more than 10 percent. In addition, Deputy KPAI, Apong Herlina said that violence against children in the school environment occurred in various types both carried out by teachers and between students. Cases of violence also occur evenly in almost all regions in Indonesia. This note is based on the results of the KPAI survey in 9 provinces of more than 1,000 female students both from the Elementary School/MI, Junior High School/MTs, and Senior High School/MA levels. This survey showed 87.6 percent of students claimed to experience acts of violence. Both physical and psychological violence, such as being reprimanded, beaten, yelled, insulted, are given a negative stigma to be hurt by sharp objects (Yulianto, 2016). Therefore, the Indonesian Child Protection Commission/Komisi Perlindungan Anak Indonesia (KPAI) encouraged all Education Offices to create child- friendly school.

One item demanded by Indonesian children to go to the government at the 2016 Indonesian Children's Congress in Mataram is "Make our school and curriculum child friendly up to remote areas" (DP3AKB Jabar, 2016). KPAI encourages the Ministry of Women's Empowerment and Child Protection, the Ministry of Education and Culture, and the Ministry of Religion of the Republic of Indonesia to work together to create safe and comfortable schools. This was followed up in the Child-Friendly School/Sekolah Ramah Anak (SRA) program. Acceleration of SRA must be carried out throughout the Ministry of Institutions/Kementerian Lembaga (KL) (Harsono, 2018). Based on this program, this article was written with the aim of providing an overview of Child-Friendly School that need to be implemented to prevent bullying in Indonesia.

\section{Method}

In this study, a search for published literature was conducted through various database including E-Journals, Journal School of Health, Google, UNICEF and UN website, Google Scholar, and reference lists from key studies were also used to find information relevant to this topic. Articles were limited to primarily peer-reviewed journals, with scholarly works included to provide background and support information about the topic published between 2004 and 2019. The reference lists of key articles were searched to add support for several discussions throughout the paper and obtained by conducting Google searches for their titles. The following key words were searched : bullying, school bullying, school bullying prevention, school bullying in Indonesia, Sekolah Ramah Anak, and Child-Friendly School. Besides, correspondence with some researchers were conducted. The correspondence was conducted through e-mail with Olweus. It aims to discuss and identify the exact definition of bullying and how to measure bullying. 


\section{Definition of Child-Friendly School}

The word 'school' in language, comes from Latin, namely skhole, scola, scolae, and schola which means "free time". According to Sokobere (2011) in Krisnamurti, explain more about the meaning of the word "free time". Free meaning has unlimited time to observe what is happening around it and what goes on in itself; have free time to listen, and to see clearly. Free that has an inner meaning of calm, no motive, and therefore no direction. This is free, and only in this situation can the mind learn, not only science, history, mathematics, but also about itself.

Child-Friendly School was developed by UNICEF which uses the concept of childfriendliness as an ideology by providing safe and protected schools, trained educators, adequate resources and learning environments. According to UNICEF Innocenti Research in the word 'child-friendly', child-friendly means guaranteeing the rights of children as citizens of the city. Whereas Indonesian children in society, the word 'child-friendly' means an open society, involving children and adolescents to participate in social life, and encouraging child growth and welfare. Therefore, it can be said that child-friendly means placing, treating and respecting children as human beings with all their rights. Thus child-friendly can be interpreted as a conscious effort to guarantee and fulfill children's rights in every aspect of life in a planned and responsible manner. The main principles of this effort are nondiscrimination, the best interests of the child, the right to life, survival, and the development and appreciation of children's opinions.

As stated in article 4 of Act Number 23 of 2002 concerning child protection, states that children have the right to be able to live grow, develop, and participate fairly according to human dignity, and get protection from violence and discrimination. Mentioned above, one of them is participating which is described as the right to opinion and hear his voice. ChildFriendly Schools are schools that openly involve children to participate in all activities, social life, and encourage child growth and welfare.S

Based on this explanation, the Child-Friendly School/Sekolah Ramah Anak (SRA) is a school that is open, safe, healthy, green, inclusive, and comfortable for physical, cognition, and psycho-social development for children and adolescents including children who need special education and/or special service education to participate in social life, as well as encouraging child growth and development.

\section{Definition of Bullying}

The term 'bullying' was introduced by Daniel Olweus. In the 1990s, a lot of research on bullying adopted the definition of bullying it made. Olweus (Flynt \& Morton, 2006) defines 'bullying' as an aggressive behavior that is intended to harm or make individuals feel troubled, occur repeatedly from time to time and takes place in a relationship that has an imbalance of power or strength in it. Olweus in the Olweus Bully/Victim Questionnaire (Solberg \& Olweus, 2003) dividing aspects of bullying includes:

1. Verbal: say something that means to hurt or laugh at someone (making it a joke) by calling/greeting him/her with a name that hurts him/her, telling lies or spreading false rumors about someone.

2. Indirect: completely rejecting or removing someone from a friendship group or leaving it intentionally or sending notes and trying to make other students dislike them.

3. Physical: Hit, kick, push, play or terrorize and do things that aim to hurt. 
There are 7 factors that influence the occurrence of bullying (Astuti, 2008):

1. Class differences (seniority), economics, religion, gender, ethnicity, or racism. Basically, the difference (especially if the difference is extreme) of an individual with a group where he/she joins, if it cannot be addressed properly by members of the group, can be a factor in bullying.

2. Seniority tradition. Seniority that is wrongly interpreted and used as an opportunity or reason to bully juniors sometimes does not stop in a period. This is often an unwritten rule that is passed down from generation to generation. For example, one of the Senior High Schools in Jakarta has an unclear reason, that is, class X students are prohibited from passing through class Y. If, it is violated, the student who passes by will be yelled at. Students do not dare to violate this rule, because the prohibition has been going on for generations for many years.

3. Seniority, as one of the bullying behaviors, is often extended by students themselves as latent events. For them the desire to continue the problem of seniority is for entertainment, revenge, jealousy or seeking popularity, continuing traditions or showing power.

4. Families that are not harmonious. The complexity of family problems such as absence of a father, mother suffering from depression, lack of communication between parents and children, divorce or disharmony of parents and socioeconomic incapacity are the causes of significant acts of aggression.

5. School situation that is not harmonious or discriminatory. Bullying can also occur if ethical supervision and guidance from teachers is low, schools with very rigid discipline, improper guidance and inconsistent regulations.

6. Individual/group character. The character of individuals/groups that can be a factor in the occurrence of bullying is revenge or jealousy, the enthusiasm of wanting to control the victim with physical power and sexual attraction, to increase the popularity of the perpetrators among peers, and the perception of the wrong value of the victim's behavior. Victims often feel that they deserve to be treated as such (bullied), so that the victim just silences it repeatedly on him.

According to Prasetyo (2011), bullying can have short-term and long-term impacts.

The short-term impact of bullying is to cause feelings of insecurity, isolation, feelings of low self-esteem, depression or suffering from stress that can lead to suicide. The long impact is that victims of bullying can suffer emotional and behavioral problems. Prasetyo (2011) also explained that the long-term effects of bullying may not be realized by both the perpetrators, victims and teachers and parents because the impact is more psychological and emotions that are not visible and the process is very slow, long lasting and does not appear immediately.

\section{The Purpose of Creating Child-Friendly School}

Based on the Child-Friendly School Guidelines compiled by the Ministry of Women Empowerment and Child Protection of the Republic of Indonesia, the policy of making ChildFriendly School is to be able to fulfill, guarantee and protect children's rights, and ensure that education units are able to develop children's interests, talents and abilities and prepare children for responsible for a life that is tolerant, mutual respect, and cooperates for the progress and spirit of peace. The education unit is expected to not only give birth to generations that are intellectually intelligent, but also give birth to generations that are emotionally and spiritually intelligent. 


\section{Principles for Organizing Child-Friendly School}

According to the KPAI Commissioner for Education, Retno Listyarti, Child-Friendly Schools have only been understood as limited to schools which are safe from violence. Whereas in fact Child-Friendly Schools are safe and comfortable schools to deliver Indonesian children to become a reliable next generation. In addition, according to Retno Listyarti (Harsono, 2018), Child-Friendly Schools are not just zero violence in the form of physical, psychological, and sexual violence that occurs in the school environment. But the principle of Child-Friendly Schools must also have a canteen that provides healthy food and is obliged to create a school environment that is physically safe, beautiful and green. Schools must have disaster evacuation routes, smoke free, drug free, and have a complaint number.

National Coordinator of the Indonesian Education Monitoring Network/Jaringan Pemantau Pendidikan Indonesia (JPPI), Ubaid Matraji (in Abdi, 2019), indicator of ChildFriendly Schools, that there should be no violence in schools, both physical and nonphysical, facilities and infrastructure in schools must support children, the learning process must apply positive discipline patterns and the establishment of effective communication between children, parents, and schools.

Safe and Supportive Schools Model developed by the Department of Education of United States based on listening sessions and consultations with researchers and practitioners can also be one of the references in conducting Child-Friendly Schools. This model includes three main components: Engagement, Safety, and Environment.

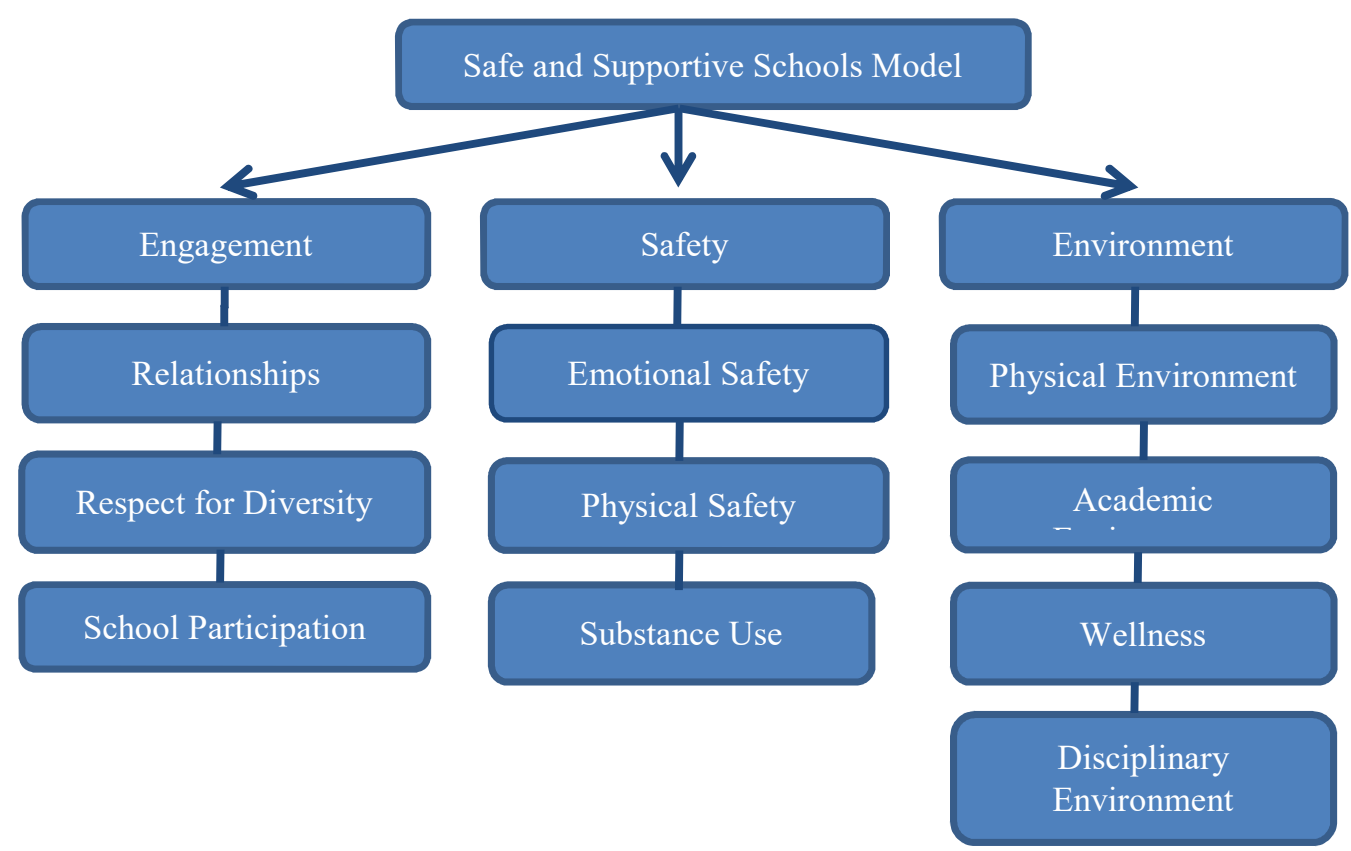

Fig. 1. Safe and Supportive Schools Model developed by the Department of Education of

United States 
School engagement is very important in building a positive academic success and school atmosphere. School engagement consists of relationships, respect for diversity, and school participation. Analysis of data from the Longitudinal Study of National Education in the United States shows that supportive and caring relationships between students and teachers, as well as positive perceptions of teachers about the efforts of students in the classroom, produce higher academic achievement for students.

School Safety refers to the security of school settings and school-related activities that are felt and experienced by all stakeholders, including students, teachers, school staff, families, and communities. School safety includes emotional and physical safety, and is influenced by the positive and negative behavior of students, teachers, and school staff, and the presence of drug use in the school environment. Students' perceptions of feeling or not feeling safe at school have proven to have an impact on their educational outcomes. School environments characterized by victimization and hostility were found to be associated with lower levels of involvement and achievement in mathematics and reading; and personal experience with threats, theft, or attacks on school has been shown to increase the likelihood of students dropping out of school.

The use and sale of drugs in schools is also associated with negative educational outcomes for students. A study conducted by Department of Education of California found that schools that reported having a large percentage of students who said they were drunk or offered drugs in the school environment showed lower scores on academic achievement than other schools whose students did not report this experience.

School environment refers to the extent to which school settings prioritize student safety and student health. The environment referred to here includes all aspects of the school-its academic component, its physical and mental health support and services, its physical building and location, and its disciplinary procedures.

\section{Child-Friendly School as Bullying Prevention}

In Indonesia, the process of education which still makes children an object and the teacher as the party that is always right, easily creates bullying in schools/madrasa. Schooling is not always a pleasant experience for children. Data from KPAI (2014-2015) concerning Cases of Violence (Physical, Psychic, Sexual Violence and Neglect of Children), as many as 10\% were carried out by teachers. Data from KPAI (2013) explained the forms of violence that were mostly found in the form of bullying, as well as forms of punishment that did not educate students, such as pinching (504 cases), shouting out loud (357 cases) and reprimanding ( 379 case). The details of the data on child violence in the world of Education reported from 2011 to 2017 reached 2,961 cases so that it became the basis that ChildFriendly Schools needed to be implemented.

The absence of violence in schools is one factor among the positive factors that characterize a safe and effective school. Previous researchers have framed the problem of school violence into two conceptual models of school security which include the concepts of development and education and emphasize the prevention and effectiveness of schools (Jimerson \& Furlong, 2006). Recognizing that no school can create 100 percent of a friendly school environment, Sprague \& Walker (2005) conceptualizes child-friendly schools in a bipolar dimension.

This bipolar dimension is illustrated in a series from unsafe to safe. Relative school security is shown in terms of the number and nature of the risk factors and protective factors. Like individuals, the risk factors and conditions direct the school to unsafe conditions. The 
greater the number of risk factors or conditions, the greater the risk, and the longer they become evidence, the greater the destructive impact on school security. Protective factors have the potential to reduce the destructive impact of risk conditions on school status and operations. Schools can be distributed along this dimension in terms of performance indicators that document the relative safety or insecurity of their schools - for example, the number of victimization at school; crime in school and in the surrounding environment; the number of examples of discipline, suspension, and expenditure per student and for the entire school; level of academic achievement; presence; the quality of school discipline training; school social climate; presence or absence of gang activity, and so on. Although there is no reliable composite index of these actions, it is likely that this concept can be developed and used to find individual schools along this continuum (Sprague \& Walker, 2005)

School security continuity cannot be analogized in absolute terms as safe or unsafe, but rather analogous to comparative terms such as safer versus less secure. It is the responsibility of school leaders and communities to do everything in their power to maximize the safety and security of their schools. As with social conditions (family and community environment) in a deteriorating environment, the challenge for educators - maintaining an acceptable level of school security - is difficult to develop. School security focus requires greater investment of resources if it is not allocated for positive student social and academic development (Sprague \& Walker, 2005).

\section{Discussion}

Child-Friendly Schools/Sekolah Ramah Anak (SRA) can be realized if education centers (schools, families, and communities) work together. Family is the closest community of children. The ideal family environment for children is a harmonious family environment, both physically and mentally. In addition, creating a positive environment in school is also important. Research conducted by Maghfirah \& Rachmawati (2010) shows that the more positive the school environment is, the lower the tendency of students to bullying. According to Prasetyo (2011), there are several steps that can be applied by schools to prevent bullying, i.e. changing the way to educate and how to treat students, build an active communication network with parents, provide proper understanding of bullying to teachers, students and parents through workshops, training or seminars, declaring an anti-bullying campaign involving the active role of all elements of the school, from teachers, employees, students, parents, alumni, and the surrounding community, and as a prevention as well as handling bullying cases, schools need to provide some kind of bullying center for students. Counseling guidance in schools can add this function and act as a place of complaint that is very confidential, meaning that the identity of the reporting victim will be kept confidential. This section also has the role of providing counseling and therapy for students who are victims and perpetrators.

\section{Result}

Based on various school bullying reported by KPAI and other cases happened and researched, Child-Friendly Schools are supposed to be realized by following its principles mentioned in previous section. Its implementation also should be supervised by children's environment surrounding (family, friends, school itself, their society, and the government). It is important because according to previous research shows that the more positive the school 
environment is, the lower the tendency of students towards bullying.

\section{Conclusion}

Schools are not always a safe place for their children to experience violence such as bullying in schools. Bullying that occurs in children in the learning environment can be emotional, physical and psychological, and can occur from mild to very violent acts of violence. Bullying in schools can cause short-term and long-term effects for children's development both physically and mentally. Therefore, schools as one of the closest environments for children after families need to create a conducive environment known as Child-Friendly Schools. The implementation of Child-Friendly Schools (SRA) is carried out by referring to six important components, i.e. SRA policy, implementation of child-friendly learning processes, trained educators and education personnel, children's rights and SRA, SRA facilities and infrastructure, participation of children, and participation of participation of parents, institutions community, business world, other stakeholders, and alumni.

\section{References}

[1] Flynt, S.W. Morton, R.C. 2006. Alabama Elementary Principals' Perception of Bullying. Education, 2, 187-191.

[2] Hadiyono, V., \& Saraswati, R. (2016). Bullying at schools and its prevention through the school rules (case study in ten senior high schools in semarang, Indonesia), Proceedings of $1^{\text {st }}$ international conference on women and children legal and social issues, 105-112

[3] Hernandez, T. J., and S. R. Seem. 2004. A safe school climate: A systemic approach and the school counselor. Professional School Counseling 7 (4): 256-62.

[4] Jimerson, S. R., \& Furlong, M. J. (2006). The handbook of school violence and safety. Mahwah, NJ: Erlbaum.

[5] Maghfirah, U., \& Rachmawati, M.A. (2010). Relationship Between School Climate and Bullying Behavior Tendency. Faculty of Psychology and Social Cultural Science of Indonesian Islam University

[6] Prasetyo, A.B.E. (2011). Bullying at School and It's Future Impact. El Tarbawi Journal of Islamic Education, 1(4).

[7] Solberg, M.E. Olweus,D. 2003. Aggressive Behaviour. Prevalence Estimation of School Bullying With the Olweus Bully/Victim Questionnare, X, 29, 239-268.

[8] Sprague. J. R., \& Walker, H.M. (2010). Building safe and healthy schools promote school Building Safe and Healthy Schools to Promote School Success:Critical Issues, Current Challenges and Promising Approaches. Institute on Violence and Destructive Behavior, University of Oregon.

[9] UNHCR The UN Refugee Agency. (2007). Safe Schools and Learning Environment : How to Prevent and Respond to Violence in Refugee Schools. Technical Support Section Division of Operational Services UNHCR Geneva

[10] Wilson, D. (2004). The interface of school climate and school connectedness and relationships with aggression and victimization, Journal School of Health, 74(7)

[11] Wright, C., Mannathoko, C., \& Pasic, M. Children Friendly Schools Manual. UNICEF's Division of Communication. 